\title{
SUCESSÃO NA UNIÃO ESTÁVEL: A INCONSTITUCIONALIDADE DO ARTIGO 1.790 DO CÓDIGO CIVIL
}

\author{
[ver artigo online]
}

Estefany Laia Silvano ${ }^{1}$

\begin{abstract}
RESUMO: O presente artigo científico visa demonstrar, através de uma exploração pelos tipos de constituição de família no Brasil, as regras sucessórias relativas a cônjuges e companheiros. A discussão consiste no fato do legislador constitucional ter normalizado de forma igualitária perante a lei ambos os institutos, atribuindo à união estável posição de entidade familiar, o que, equivocadamente, é contrariado pela legislação infraconstitucional, no tocante, principalmente, a regulamentação dos direitos sucessórios dos companheiros. Dessa forma, este artigo científico se baseará em uma comparação entre os institutos da união estável e do casamento, além de destacando posições doutrinárias e jurisprudências sobre o tema, além de diferenciar cada tipo de entidade familiar. É de conhecimento geral que existe no ordenamento jurídico uma hierarquia entre os institutos legais, em que leis infraconstitucionais devem estar de acordo com a Lei Maior. No entanto, tratou o Código Civil de 2002 de contrariar diversos elementos constitucionais contemporâneos do conceito de família, tendo em vista que em seu artigo 1790, regulamentou a sucessão do companheiro de forma inconstitucional, amparando de forma injusta as relações de afeto previstas na família atual, dando preferência a laços biológicos, de forma contraria ao entendimento atual de família.
\end{abstract}

Palavras-chave: Entidade familiar. União estável. Inconstitucionalidade. Sucessão.

\section{SUCCESSION IN THE STABLE UNION: THE UNCONSTITUTIONALITY OF ARTICLE 1.790 OF THE CIVIL CODE}

\begin{abstract}
This scientific article aims to demonstrate, through an exploration of the types of family formation in Brazil, the succession rules related to spouses and partners. The discussion consists in the fact that theconstitutional legislator has equalized both institutions before the law, attributing to the stable union the position of a family entity, which, mistakenly, is contradicted by the infraconstitutional legislation,regarding, mainly, the regulation of inheritance rights. of companions. Thus, this scientific article willbe based on a comparison between the institutes of stable union and marriage, in addition to highlighting doctrinal positions and jurisprudence on the subject, in addition to differentiating each type of family entity. It is common knowledge that there is a hierarchy in the legal system between legal institutes, in which infraconstitutional laws must be in accordance with the Greater Law. However, the Civil Code of 2002 tried to contradict several contemporary constitutional elements of the concept of family, considering that in its article 1790, it regulated the succession of the partner inan unconstitutional way, unfairly supporting the relationships of affection foreseen in the current family. , giving preference to biological ties, contrary to the current understanding of family.
\end{abstract}

Keywords: Family entity. Stable union. Unconstitutionality. Succession.

1 Pós-graduanda em Direito Constitucional e Público, União brasileira de faculdades. Rio de Janeiro - RJ. E-mail: estefanylaiasil@gmail.com 


\section{INTRODUÇÃO}

Primeiramente, o presente artigo científico tem o objetivo de apresentar uma visão geral dos diferentes tipos de família, dentre a matrimonializada e a monoparental, além de explicar ao leitor os conceitos de entidades familiares e união estável.

Analisa-se, posteriormente, os direitos sucessórios do cônjuge e do companheiro, apresentando as diferenças entre eles, além de destrinchar todos os seus aspectos. É sabida que disparidade de tratamento entre cônjuges e companheiros é uma questão histórica enfrentada pelo Direito Civil brasileiro.

Nesse viés, esse estudo examina o artigo 1790 do Código Civil de 2002, tendo como temática fundamental a compreensão de como ocorre a sucessão nas uniões estáveis de acordo com o ordenamento pátrio vigente. Para tanto, far-se-á uma comparação com o que dispõe a legislação infraconstitucional no que tange ao casamento, com o intuito de se ter um maior aprofundamento da nítida importância conferida ao matrimônio frente a união estável.

O respaldo constitucional do referido artigo é questionado, tendo em vista que elementos constitucionais básicos da família, como a afetividade e a solidariedade, foram deixados de lado, para privilegiar laços biológicos que, em muitas vezes, não condizem com a própria vontade do autor da herança. Com a modificação do conceito de família e a conquista de maior espaço pelo cônjuge em relação ao Direito Sucessório, infelizmente algumas injustiças ainda permanecem no que diz respeito aos direitos a título de sucessão causa mortis, nas relações derivadas de uniões estáveis e do casamento.

Ao elevar a união estável como entidade familiar, a Constituição consagrou a sua proteção estatal, ao lado do casamento, como instituição. Porém, no tratamento sucessório o Código Civil estabelece tratamento diferenciado, destacando-se a questão acerca da participação do colateral na concorrência sucessória. Em relação à sucessão do cônjuge, não existe a concorrência junto aos colaterais; porém na situação de existência de união estável, o companheiro concorreria com os colaterais na situação de não existirem descendentes nem ascendentes.

Nota-se que o tratamento diferenciado, onde se tem a concorrência com colaterais somente na sucessão do companheiro, pode-se considerar uma possível valorização da família de origem do casamento em relação à da união estável. 
Existe a possibilidade de relacionar essa diferenciação com uma valorização da família oriunda do casamento, indo contra aos preceitos constitucionais que reconheceu a união estável como entidade familiar, não possibilitando uma hierarquia entre diferentes tipos de origem familiar, ofendendo os princípios da igualdade, dignidade humana e proibição de retrocesso.

\section{TIPOS DE FAMÍLIA E A UNIÃO ESTÁVEL}

\subsection{Entidades familiares}

A família, em conjunto com o contrato e os modos de apropriação, tais como posse e propriedade, são os três pilares fundamentais do direito civil, na qual o estado tem por obrigação promover a segurança das pessoas que deles se cercam. Como conceitua MARIA BERENICE DIAS: “A família é o núcleo natural e fundamental da sociedade e tem direito à proteção da sociedade e do Estado"2.

É, portanto, uma estrutura pública como uma relação privada, pois identifica o indivíduo como integrante do vínculo familiar e também como partícipe do contexto social.

Ela é a célula mãe das sociedades, na qual é necessário um eterno repensar e refletir sobre essa instituição que é uma das primeiras e mais importantes, e que nasceu conjuntamente com o próprio homem. No passado, somente o casamento merecia a proteção constitucional, porém, com a consagração do princípio da dignidade humana como cláusula pétrea da Constituição Federal de 1988 (art. 1º III, CF/88), além dos princípios básicos da família moderna como o da liberdade e da igualdade, fez com que uma nova ordem jurídica que descarta o caráter econômico e de procriação da família fosse estabelecida, tendo como vínculo principal à afetividade.

No campo da demografia e da estatística, as unidades de vivência dos brasileiros são objeto de pesquisa anual e regular do IBGE, intitulada Pesquisa Nacional por Amostragem de Domicílios (PNAD). Os dados advindos PNAD têm revelado um perfil das relações familiares distanciado dos modelos legais, logo após o advento da Constituição de 1988. São unidades de vivência encontradas na experiência brasileira atual, entre outras:

2 DIAS, Maria Berenice. Alimentos a Vida. In: Revista Jurídica Consulex. Ano XII, n. 286, dez. 2008. 
a) par andrógino, sob regime de casamento, com filhos biológicos;

b) par andrógino, sob regime de casamento, com filhos biológicos e filhos adotivos, ou somente com filhos adotivos, em que sobrelevam os laços de afetividade;

c) par andrógino, sem casamento, com filhos biológicos (união estável);

d) par andrógino, sem casamento, com filhos biológicos e adotivos ou apenas adotivos (união estável);

e) pai ou mãe e filhos biológicos (comunidade monoparental);

f) pai ou mãe e filhos biológicos e adotivos ou apenas adotivos (comunidade monoparental);

g) união de parentes e pessoas que convivem em interdependência afetiva, sem pai ou mãe que a chefie, como no caso de grupo de irmãos, após falecimento ou abandono dos pais;

h) pessoas sem laços de parentesco que passam a conviver em caráter permanente, com laços de afetividade e de ajuda mútua, sem finalidade sexual ou econômica;

i) uniões homossexuais, de caráter afetivo e sexual;

j) uniões concubinárias, quando houver impedimento para se casar de um ou de ambos companheiros, com ou sem filhos;

1) comunidade afetiva formada com "filhos de criação", segundo generosa e solidária tradição brasileira, sem laços de filiação natural ou adotiva regular.

Sendo assim, há que se falar na similaridade entre os perfis familiares mencionados acima. Isso ocorre devido à existência de elementos como afeto, apresentação familiar perante o corpo social, o que afirma a identidade desse perfil, e estabilidade.

O direito também atribui a certos grupos sociais a qualidade de entidades familiares para determinados fins legais, a exemplo da Lei n. ${ }^{\circ}$ 8.009, de 29.03.90, sobre a impenhorabilidade do bem de família; da Lei n. ${ }^{\circ} 8.425$, de $18.10 .91^{3}$, sobre locação de imóveis urbanos, relativamente à proteção da família, que inclui todos os residentes que vivam na dependência econômica do locatário; dos artigos 183 e 191 da Constituição, sobre a usucapião especial, em benefício do grupo familiar que possua o imóvel urbano e rural como moradia.

Desse modo, muitos doutrinadores, ao se posicionarem sobre o tema, compreendem que a unidade familiar decorrida do casamento possui preferência frente aos demais modelos

\footnotetext{
${ }^{3}$ Disponível em: http://www.planalto.gov.br/ccivil_03/leis/18245.htm. Acesso em: 17 jul. 2020.
} 
de entidades familiares, considerando, especialmente os ditames do artigo 226, parágrafo terceiro, da chamada Constituição Cidadã.

\subsection{A Família Matrimonializada}

O casamento já existe há muito tempo, desde tempos remotos sobre a influência da igreja, do patriarca, do estado e do marido. Hoje o casamento legitima pela liberdade na procura da felicidade em estreita relação com o respeito à dignidade da pessoa humana. Até o advento da Constituição de 1988, o casamento era a única entidade familiar prevista expressamente, o que mudou a partir dessa data. Com aproximadamente 150 dispositivos no código civil brasileiro do ano de 2002, o que o faz a temática do direito de família com o maior número de regulamentação codificada, não há uma definição expressa acerca do seu conceito na lei, porém sendo sempre reconhecido como um importante fundamento social. É para Clóvis:

(...) um contrato bilateral e solene, pelo qual um homem e uma mulher se unem indissoluvelmente, legitimando por ele suasrelações sexuais; estabelecendo a mais estreita comunhão devida e de interesses, e comprometendo-se a criar e educar aprole que de ambos nascer (BEVILÁQUA, 1976, p. 34)

Outrossim os efeitos jurídicos do casamento estão previstos no artigo 1565 a 1570 do Código Civil, tais como a fidelidade recíproca, a vida em comum no domicílio conjugal, a mútua assistência, o sustento, a guarda e educação da prole, a emancipação do cônjuge menor de idade, o ingresso na ordem sucessória, a imediata vigência do regime matrimonial e o direito a pensão alimentícia em caso de dissolução do casamento. Não se pode negar que o constituinte teve a intenção de preservar o casamento em uma posição de destaque como um modelo adequado de relação familiar no referido artigo constitucional 226, haja vista que exige um ato jurídico solene indispensável a sua realização além de reconhecer a possibilidade de conversão de união estável em casamento, clarificando o prestígio do mesmoatravés do $\S 1^{\circ}$. Desse posicionamento discorda LOBO (2009, p. 148), ao afirmar que ainda 
que: "o casamento seja sua referência estrutural, cada entidade é dotada de estatuto jurídico próprio, sem hierarquia ou primazia um sobre o outro" 4

Contudo, considerando as transformações sociais ao longo da evolução humana, o casamento é tido, na contemporaneidade, como uma forma de aprisionamento por muitos indivíduos, de forma que tal instituição reafirma os estereótipos e a desigualdade de gêneros dentro da sociedade. Sendo assim, é imprescindível a mudança não só de mentalidade, como o desarraigamento por parte da legislação hodierna de termos e definições que atribuam ao matrimônio o status de "obrigação", e não de uma união por livre vontade das partes - estando em consonância com os costumes e nova visão social acerca dessa entidade.

\subsection{Família monoparental}

Contrariando a composição familiar tradicional, formada por ambos responsáveis, pai e mãe, a família monoparental é aquela composta por apenas um desses indivíduos, que sustenta a todos, e seus filhos. No entanto, por ser um modelo que não atende ao conservadorismo familiar, os componentes dessa instituição, sobretudo os filhos menores, acabam sofrendo condutas discriminatórias por parte dos demais cidadãos - o que pode acarretar em sequelas ao longo da vida adulta.

Tal fenômeno social sempre existiu, haja vista a ocorrência de mães solteiras e mulheres abandonadas com seus filhos, mas passou a ser mais percebida nos últimos vinte anos através do aumento do número de divórcios conjugais. Até a promulgação da constituição federal de 1988, através do artigo $226^{5}$, não era categoricamente protegida no mundo jurídico.

O primeiro país que empregou o termo de monoparentalidade foi a França no ano de 1981, mesmo tal assunto já estar sendo tratado na Inglaterra desde 1960 através dos

\footnotetext{
${ }^{4}$ LOBO, Paulo Luiz Netto. Entidades Familiares Constitucionalizadas: Para Além Do Numerus Clausus. Revista IBDFAM, 12, jan/fev/mar. 2002, p. 40-55.

5 Artigo 226 da CF/88: A família, base da sociedade, tem especial proteção do Estado. $\S 4^{\circ}$ - Entende-se, também, como entidade familiar a comunidade formada por qualquer dos pais e seus descendentes.
} 
levantamentos estatísticos do país. Os fatores determinantes da monoparentalidade, segundo BRAVO E SOUZA ${ }^{6}$ são:

O celibato, o divórcio ou a separação, a união livre, as mães solteiras, a liberdade sexual, o controle de natalidade, a viuvez, apossibilidade de adoção por maior de 21 anos independente do estado civil e até mesmo o desejo de maternidade independente das mulheres através de inseminação artificial. (BRAVO E SOUZA, 2002)

Nesse viés, alguns deveres dos pais para com seus filhos são a proteção e acesso ao ensino, fiscalização, responsabilidade civil, dentre outros. Ainda, dada as modificações nas relações sociais, o índice de famílias monoparentais, acompanhadas de uma vida financeira dificultada, vem ganhando espaço em detrimento da biparentalidade.

Por conseguinte, é notório que a implementação de programas estatais que visem à concessão de oportunidades para tais entidades familiares é indispensável para, não só proteger as crianças e adolescentes, como também auxiliar nas questões financeiras a que estas famílias estão vulneráveis.

\subsection{A união estável}

Como tal entidade só foi reconhecida a partir da Constituição da República de 1988, anteriormente, a relação entre homem e mulher que não fosse regida pela instituição formal do casamento era tida como ilícita e imoral, não sendo poupados os indivíduos que optavam viver juntos sem uma formalização legal das constantes críticas sociais.

Nesse sentido, tal caráter negativo da união atingia também a esfera jurídica, dado que ela era tida como, no máximo, sociedade de fato. Contudo, é paradoxal que o país que se constitui em Estado Democrático de Direito seja indiferente à proteção não concedida a todos os seus cidadãos.

\footnotetext{
${ }^{6}$ BRAVO, Maria Celina; SOUZA, Mário Jorge Uchoa. As entidades familiares na Constituição. Jus Navigandi, Teresina, ano 6, n. 54, fev. 2002. Disponível em: https://jus.com.br/artigos/2665/as-entidades-familiares-naconstituicao. Acesso em: 17 jul. 2020.
} 
Sendo assim, o Código Civil de 2002, dos artigos 1.723 a 1.727 versa sobre a união estável, constando a definição do termo e deveres de ambos os pertencentes a tal relação (artigo 1724). Ademais, a união é reconhecida de forma mais célere a partir do período emque é possível constatar que os cidadãos começam a dividir o mesmo lar.

O regime de bens a partir do início da união estável é o de comunhão parcial de bens e a extinção da união estável termina como se inicia, sem nenhum ato formal fundada exclusivamente na separação de fato. O artigo 226, $\S 3^{\circ}$ da CF e o artigo 1.726 do CC expressam a devida facilitação da conversão da união estável em casamento. Tal conversão foiuma vitória dos indivíduos conservadores na constituinte, tendo em vista que está maisrelacionada a um valor moral do que a um meio mais simples para regularizar relações sem um vínculo formal, devolvendo aos indivíduos a dignidade de um casamento em detrimento a uma "relação inferior de segunda classe", como é vista com frequência por indivíduos em nossa sociedade. O reconhecimento explícito da união estável através da CF de 1988 foi um progresso na medida em que promoveu segurança jurídica a mulheres e homens independentes e descompromissados que decidem se unir sem nenhum fim econômico pautados em relações de afeto um para com o outro.

Segundo a opinião de MARIA HELENA DINIZ (1990, p. 223-324), para a identificação da existência de união estável, faz-se necessária a presença de alguns requisitos essenciais, tais como:

1) continuidade das relações sexuais, desde que presentes, entre outros aspectos a estabilidade, ligação permanente para fins essenciais à vida social, ou seja, aparência de casamento;

2) ausência de matrimônio civil válido entre os parceiros;

3) notoriedade das afeições recíprocas, afirmando não se ter concubinato se os encontros forem furtivos ou secretos, embora haja prática reiterada de relações sexuais;

4) honorabilidade, reclamando uma união respeitável entre os parceiros (RT, 328:740, RTJ, 7:24);

5) fidelidade da mulher ao amásio, que revela a intenção de vidaem comum; 
6) coabitação, uma vez que o concubinato deve ter a aparênciade casamento, com a ressalva à Súmula $382 .{ }^{7}$

Na opinião de alguns juristas deveriam estar presentes, juntamente com a demonstração pública de convivência, a coabitação sob um mesmo teto, muito embora a jurisprudência tenha caminhando em sentido diversos, com alguns julgados ${ }^{8}$.

Portanto, retirando os pontos controvertidos, quais sejam a coabitação e o período de convivência, os demais requisitos, se presentes, caracterizam existência de família formada pela união estável amparada juridicamente, não deixando de se mencionar um dos requisitos primordiais, a não vedação ao casamento, ou seja, os conviventes não podem ser impedidos para o matrimonio civil, do contrário, estar-se-ia tratando de concubinato ou uma das formas de família simultânea, outro modelo de família contemporânea e não a família formada pela união estável.

\section{DIREITO SUCESSÓRIO DO CÔNJUGE E DO COMPANHEIRO}

\subsection{Do cônjuge}

O Código Civil considera o cônjuge herdeiro necessário, com os descendentes e ascendentes (art.1.845). Segundo o art. 1.846 do C.C., pertence aos herdeiros necessários, de pleno direito, a metade dos bens da herança, constituindo a legítima, devendo ser considerado o cônjuge herdeiro necessário privilegiado, pois concorre com os descendentes e com os ascendentes do de cujus, portanto, ora está na $1^{\text {a }}$ classe dos herdeiros legítimos, concorrendo com os descendentes, ora na $2^{\mathrm{a}}$ classe sucessória, concorrendo com os ascendentes, e ocupa,

\footnotetext{
${ }^{7}$ DINIZ, Maria Helena. Curso de Direito Civil Brasileiro. Direito de Família. São Paulo: Saraiva, 1990, p. 223 324.Vol. 5.

${ }^{8} \mathrm{O}$ art. $1^{\text {o }}$ da Lei $\mathrm{n}^{\circ}$ 9.278/96 não enumera a coabitação como elemento indispensável à caracterização da união estável. Ainda que seja dado relevante para se determinar a intenção de construir uma família, não se trata de requisito essencial, devendo a análise centrar-se na conjunção de fatores presente em cada hipótese, como a affectio societatis familiar, a participação de esforços, a posse do estado de casado, a fidelidade, a continuidade da união, entre outros, nos quais se inclui a habitação comum. A ausência de prova da efetiva colaboração da convivente para a aquisição dos bens em nome do falecido é suficiente apenas para afastar eventual sociedade de fato, permanecendo a necessidade de se definir a existência ou não da união estável, pois, sendo esta confirmada, haverá presunção de mútua colaboração na formação do patrimônio do de cujus e consequente direito à partilha, nos termos do art. $5^{\circ}$ da Lei $n^{\circ} 9.278 / 96$. Recurso especial conhecido e provido.
} 
sozinho, a $3^{\text {a }}$ classe dos sucessíveis. Esta posição sucessória reconhecida ao cônjuge sobrevivente é um dos grandes avanços do novo Código Civil ${ }^{9}$.

Ainda, o artigo 1830 do referido Código versa sobre as condições do direito de sucessão após o falecimento do cônjuge, ocorrendo somente mediante a não separação judicial ou constatação de que a separação se deu devido à impossibilidade de convivência entre ambos, desde que o cônjuge sobrevivente não tenha culpa.

O Código Civil não menciona os casos de o vínculo matrimonial ter sido dissolvido pelo divórcio, ou de ter havido a anulação ou a declaração de nulidade do casamento. Nem precisava! Nessas hipóteses, sem dúvida, nem há cônjuge, que pudesse ser chamado à sucessão, embora se deva alertar para a controvertida questão do casamento putativo (C.C.,art. 1561; Código Civil de 1916, art. 221). Se a anulação ou a declaração de nulidade do casamento deu-se após o falecimento do cônjuge, estando o cônjuge sobrevivente de boa-fé, este não perde a qualidade de herdeiro, pois a sentença anulatória não tem efeito retroativo.

Em caso de bigamia, a maioria da doutrina brasileira opina que a herança será dividida, em partes iguais, entre o cônjuge legítimo e o cônjuge putativo. Conforme preconiza Pontes de Miranda ${ }^{10}$ :

Se morre o cônjuge bígamo antes de se inscrever a sentença constitutiva da nulidade do casamento, ou de anulação, há duas mulheres, ou dois maridos, com direito à sucessão, desde que se trate de casamento putativo (MIRANDA, 1960, p. 24).

A concorrência do cônjuge sobrevivente com os descendentes vai depender do regime de bens do casamento, não acontecendo se o regime foi o da comunhão universal, ou o da separação obrigatória. Se o regime foi o da comunhão parcial, a concorrência dar-se-á se o autor da herança houver deixado bens particulares (C.C., art. 1.829, I).

\footnotetext{
9 Art. 1.829. A sucessão legítima defere-se na ordem seguinte:

I - aos descendentes, em concorrência com o cônjuge sobrevivente, salvo se casado este com o falecido no regime da comunhão universal, ou no da separação obrigatória de bens (art. 1.640, parágrafo único); ou se, no regime da comunhão parcial, o autor da herança não houver deixado bens particulares; II - aos ascendentes, em concorrência com cônjuge; III - ao cônjuge sobrevivente; IV - aos colaterais.

${ }^{10}$ MIRANDA, Pontes de. Tratado de Direito Privado, $2^{a}$ ed., Rio de Janeiro: Borsoi, t. VIII, § 827, p. 24, 1960.
} 
Admitida à concorrência do cônjuge sobrevivente com os descendentes do de cujos, observando o que acima foi exposto, caberá a ele quinhão igual ao dos que sucederem por cabeça, não podendo a sua quota ser inferior à quarta parte de herança, se for ascendente dos herdeiros com que concorrer (C.C., art. 1.832). Esta solução se inspirou no art. 2.139 número I, do Código Civil português.

Pelo exposto, se o falecido deixou até três filhos, a partilha se faz por cabeça, dividindose a herança, em partes iguais, entre os filhos e o cônjuge. No caso de o de cujus possuir quatro filhos, ou mais, e tendo de ser reservada a quarta parte da herança à viúva ou ao viúvo, os filhos repartirão o restante. Por exemplo: o autor da herança tem quatro filhos. Neste caso,o cônjuge sobrevivente fica com um quarto da herança, e os três quartos restantes sãodestinados aos quatro filhos.

Mas esta reserva hereditária mínima (1/4), conferida ao cônjuge sobrevivente, pressupõe que este cônjuge seja também ascendente dos herdeiros com que concorrer, requisito que não é previsto no art. 2.139, n. 1, do Código Civil lusitano. Se o de cujus deixou descendentes, dos quais o cônjuge sobrevivente não é ascendente, será obedecida a regra geral: ao cônjuge sobrevivente caberá um quinhão igual ao dos descendentes que sucederem por cabeça.

Nesse ditame, tal reserva mínima não será aplicada quando o cônjuge que faleceu possuía filhos com outro indivíduo, advindos da relação com o cônjuge sobrevivente, não sendo, portanto, o companheiro que sobreviveu concorrente ascendente com os herdeiros.

Na falta de descendentes, são chamados à sucessão os ascendentes, em concorrência com o cônjuge sobrevivente (C.C., art. 1.836). Na concorrência com os ascendentes, já não se apresentam aquelas restrições decorrentes do regime de bens do casamento (C.C., art. 1.829, I). Mas a quota hereditária é variável: concorrendo com ascendente em primeiro grau, ao cônjuge tocará um terço da herança; caber-lhe-á a metade desta se houver um só ascendente, ou se maior for aquele grau (C.C., art. 1.837). Em falta de descendentes e ascendentes, será deferida a sucessão por inteiro ao cônjuge sobrevivente (C.C., art. 1.838).

Pelo sistema do novo Código Civil, como vimos o cônjuge já concorre com os descendentes (art. 1.832) e com os ascendentes (art. 1.837) do de cujus. E não havendo tais parentes na linha reta, o cônjuge sobrevivente é chamado à totalidade da herança, excluindo, portanto, os parentes colaterais. Todavia, o art. 582, redatado por força da Reforma do Direito de Família, de 1975, enuncia que, mesmo não havendo descendentes, nem ascendentes, o 
cônjuge concorre com irmãos e irmãs do falecido, embora tenha direito a dois terços da herança. Antes desta Reforma, o cônjuge concorria com colaterais até o $4^{\circ}$ grau. Além desta sucessão em propriedade, do qual o cônjuge saiu em posição privilegiada, como vimos o C.C ${ }^{11}$. estatui, ainda, o direito real de habitação.

Voltando-se ao antigo Código Civil, tem-se que o cônjuge só possuía o direito sobre a habitação do imóvel que dividia com o falecido caso não constituísse nova entidade familiar. Destarte, nota-se uma preocupação com o direito à moradia e dignidade do cônjuge que sobreviveu - deveres de um país que se constitui em Estado Democrático de Direito.

Entretanto, ao se observar a legislação civilista hodierna, não parece ser razoável a permanência do direito de habitação caso o cônjuge estabeleça uma nova família, posto que as necessidades dos demais familiares são colocadas à margem. Assim, há que se falar na alteração do artigo 1.831 do novo Código Civil, estando em consonância com as reais necessidades e interesses do cônjuge sobrevivente.

\subsection{Do companheiro}

A sucessão do companheiro, para começar, limita-se aos bens adquiridos na vigência da união estável. Comenta VENOSA (2011, p. 143) que "o legislador poderia ter optado em fazer a união estável equivalente ao casamento em matéria sucessória, mas não o fez'”. ${ }^{12}$

Outrossim, é indispensável fazer a diferença entre o meeiro e o sucessor hereditário. Dessa maneira, a meação advém de uma relação pautada no patrimônio, cuja formação se dá mediante dispositivo legal ou convenção estabelecida entre os indivíduos; já a sucessãoculmina na transmissão da herança para os herdeiros perante falecimento do antecessor, ocorrendo por forma de testamento ou nos ditames da lei.

Assim, tais institutos são distintos entre si, possuindo regramentos próprios, mas podendo, porém, o companheiro vivo ter direito à meação caso os bens sejam de partilha

\footnotetext{
11 Art. 1.831. Ao cônjuge sobrevivente, qualquer que seja o regime de bens, será assegurado, sem prejuízo da participação que lhe caiba na herança, o direito real de habitação relativamente ao imóvel destinado à residência da família, desde que seja o único daquela natureza a inventariar.

12 VENOSA, Sílvio de Salvo. Direito Civil: Direito das Sucessões. $11^{a}$ edição. São Paulo: Editora Atlas, 2011. Vol. 7, p. 143.
} 
comum. O meeiro já é dono de sua parte ideal antes da abertura da sucessão, por outro título. Trata-se de situação que decorre do Direito de Família, não do Direito das Sucessões. A meação do falecido é que vai ser objeto da sucessão, juntamente com outros bens, de propriedade exclusiva, se houver. Restringir a incidência do direito sucessório do companheiro sobrevivente aos bens adquiridos pelo de cujus na vigência da união estável não tem nenhuma razão, não tem lógica alguma, e quebra todo o sistema, podendo gerar consequências extremamente injustas: a companheira de muitos anos de um homem rico, que possuía vários bens na época em que iniciou o relacionamento afetivo, não herdará coisa alguma do companheiro, se este não adquiriu outros bens durante o tempo da convivência. Ficará esta mulher - se for pobre literalmente desamparada, mormente quando o falecido não cuidou de beneficiá-la em testamento, ou foi surpreendido pela morte antes de outorgar o testamento que havia resolvido fazer.

O problema se mostra mais grave e delicado se considerarmos que o C.C. nem fala no direito real de habitação sobre o imóvel destinado à residência da família, ao regular a sucessão entre companheiros, deixando de prever, em outro retrocesso, o benefício já estabelecido no art. $7^{\circ}$, parágrafo único, da Lei n. 9.278/96. Uma questão que poderá surgir, futuramente, é a de que, mesmo com o início da vigência do novo Código Civil, continuaria vigorando o parágrafo único do art. $7^{\circ}$ da Lei n o 9.278/96, que confere o direito real de habitação ao companheiro sobrevivente. Realmente, este preceito não é incompatível com qualquer norma do novo Código, podendo-se argumentar que ele sobreviverá, até porque está na linha determinada pela Constituição Federal, de reconhecimento e proteção à união estável,como entidade familiar paralela à que é fundada no matrimônio.

Observada aquela criticada limitação quanto aos bens que serão objeto da sucessão, o C.C., art. 1.790, I, dispõe que, se concorrer o companheiro sobrevivente com filhos comuns, terá direito a uma quota equivalente a que por lei for atribuída ao filho. Se concorrer com descendentes só do autor da herança, diz o art. 1.790, II, tocará ao companheiro sobrevivente a metade do que couber a cada um daqueles. Se concorrer com outros parentes sucessíveis (ascendentes, colaterais), terá direito a um terço da herança (C.C., art. 1.790, III). Finalmente, não havendo parentes sucessíveis, isto é, se o de cujos não tiver descendentes, nem ascendentes, nem colaterais até o $4^{\circ}$ grau, o companheiro sobrevivente terá direito à totalidadeda herança (C.C., art. 1790, IV). A "totalidade da herança", mencionada no inciso IV do art. 
1.790, é da herança a que está autorizado o companheiro sobrevivente concorrer. Mesmo no caso extremo de o falecido não ter parentes sucessíveis, cumprindo-se a determinação do caput do art. 1.790, o companheiro sobrevivente só vai herdar os bens que tiverem sido adquiridos na vigência da união estável. Se o de cujos possuía outros bens, adquiridos antesde iniciar a convivência, e não podendo esses bens integrar a herança do companheiro sobrevivente, passarão para o Município ou para o Distrito Federal, se localizados nas respectivas circunscrições, ou à União, quando situados no Território Federal (C.C., art. 1.844).

Alerte-se, mais uma vez, que, embora falando os incisos I a III do art. 1.790 em quotas da herança, tais incisos, obviamente, estão ligados e presos ao caput do dispositivo, e, segundo este, a sucessão do companheiro não considera o patrimônio todo deixado pelo falecido. $\mathrm{O}$ companheiro sobrevivente, nos termos do duro preceito do art. 1.790, só participará da sucessão do de cujos "quanto aos bens adquiridos na vigência da união estável". No Direito das Sucessões, aparece o tenebroso art. 1.790, afrontando o que antes havia sido dito e afirmado, colidindo com o ordenamento dos companheiros, parecendo, até, que o art. 1.790 é norma de outro Código, de outra Nação, porque não guarda correspondência alguma (muito ao contrário) com as que o novo Código Civil brasileiro, no livro do Direito deFamília, dedicou às entidades familiares formadas por uniões estáveis.

\section{A INCONSTITUCIONALIDADE DO ART. 1790 DO CÓDIGO CIVIL}

Na Constituição da República Federativa do Brasil de 1988, foram reconhecidas duas entidades familiares antes não reconhecidas. A união estável e a família monoparental. A intenção da Carta Magna foi de proteger, em relação a família, a comunhão afetiva da mesma, que promove a união de seus componentes, independente de sua origem. Entretanto, apesar de terem sido reconhecidas, é evidente o tratamento diferenciado, pois precisariam de suas regras próprias, já que cada família tem sua peculiaridade. Portanto, o Código Civil não conseguiu igualar os direitos do companheiro e do cônjuge nas regras sucessórias causa mortis expressas em lei, o que é inaceitável, pois ambos constituem família ${ }^{13}$.

\footnotetext{
13 Art. 1790. A companheira ou o companheiro participará da sucessão do outro, quanto aos bens adquiridos onerosamente na vigência da união estável, nas condições seguintes: I - se concorrer com filhos comuns, terá direito a uma quota equivalente à que por lei for atribuída ao filho; II - se concorrer com descendentes só do
} 
Já o cônjuge foi contemplado como herdeiro nos termos do artigo 1829 CC.

Está muito claro após uma leitura minuciosa dos artigos mencionados, que, na falta de descendentes e ascendentes do de cujus, o companheiro sobrevivente poderá receber apenas um terço da herança que couber aos colaterais. Já o cônjuge, em hipótese alguma terá que dividir a herança com os colaterais do falecido.

Várias outras diferenças entre a sucessão do cônjuge e a sucessão do companheiro podem ser apontadas, tais como:

a) A possibilidade de concorrência sucessória entre o cônjuge sobrevivente e os descendentes do autor da herança a depender do regime de bens do casamento. Já a concorrência do companheiro sobrevivente com os descendentes do autor da herança não depende do regime de bens, mas da forma como o patrimônio que está sendo inventariado foi adquirido;

b) O cônjuge sobrevivente foi promovido ao status de herdeiro necessário, diferentemente do companheiro sobrevivente, que é considerado herdeiro facultativo.

É claro que a união estável e o casamento são formas de constituição de família distintas, mas cabe ressaltar que essa distinção é exclusivamente de suas constituições, uma é informal e a outra formal.

Tendo isso em mente, apurou o Ministro Roberto Barroso, com suas belas palavras:

(...) não há dúvida de que a opção de constituir uma família,bem como de adotar uma determinada forma de constituição familiar é uma das mais relevantes decisões existenciais. Trata- se de uma questão que toca a intimidade de cada indivíduo, de sua vontade de seguir (ou não) tradições, crenças e sonhos, e de viver sua união segundo a sua própria concepção de vida boa. Porém, quando o Código Civil cria regimes sucessórios diversospara os casais casados e para os que vivem em união estável, restringe-se inequivocamente a autonomia de optar por um ou outro regime. Considerando-se que, na quase totalidade dos casos, o companheiro terá menos direitos sucessórios em relaçãoao cônjuge, o ordenamento jurídico impõe um ônus maior às famílias em união estável. Assim, acaba-se induzindo quem de- seja viver em união estável a adotar o modelo do casamento, por

autor da herança, tocar-lhe-á metade do que couber a cada um daqueles; III - se concorrer com outros parentes sucessíveis, terá direito a um terço da herança; IV - não havendo parentes sucessíveis, terá direito à totalidade da herança. 
receio de que seus parceiros não venham a fazer jus ao regime sucessório devido. (BARROSO, 2018, p. 20)

Após todo exposto por fim pode ser afirmado que é inconstitucional a distinção entre cônjuge e companheiro para fins sucessórios, além de ser um verdadeiro retrocesso. Está fundamentada no artigo 226, parágrafo $3^{\circ}$, da Constituição Federal ${ }^{14}$.

Defendem a idéia da inconstitucionalidade Maria Berenice Dias, Rodrigo da Cunha Pereira, Rolf Madaleno, Giselda Maria Fernandes Novaes Hironaka, dentre outros grandes doutrinadores.

De acordo com Tartuce (2014) os fundamentos que os doutrinadores possuem para julgar como inconstitucional o artigo 1.790 são:

Primeiro, porque a concorrência sucessória com os descendentes, ascendentes e colaterais somente diz respeito aos bens adquiridos onerosamente durante a união estável, o que restringe sobremaneira os seus direitos. Segundo, pois aconcorrência com os colaterais de até quarto grau dá ao companheiro apenas um terço da herança. Aliás, a concorrência com tais parentes já é considerada um absurdo jurídico, eis que o cônjuge exclui os colaterais, o que não ocorre com o companheiro. Critica-se, ainda, o fato de estar o conviventefora da ordem de vocação hereditária do art. 1.829 dacodificação privada. Por fim, não se admite o fato de o companheiro não ser herdeiro necessário, não constando na relação do art. 1.845 da codificação. (TARTUCE, 2014, p. 302)

Silvio de Salvo Venosa expôs sua crítica e inconformismo:

Poderia o legislador ter optado em fazer a união estável equiva- lente ao casamento em matéria sucessória, mas não o fez. Pre- feriu estabelecer um sistema sucessório isolado, no qual o companheiro supérstite nem é equiparado ao cônjuge nem se estabelecem regras claras para sua sucessão (VENOSA, 2011,p. 143)

14 Art. 226. A família, base da sociedade, tem especial proteção do Estado. $\S 3^{\circ}$ - Para efeito da proteção do Estado, é reconhecida a união estável entre o homem e a mulher como entidade familiar, devendo a lei facilitar sua conversão em casamento. 
Percebe-se que a união estável foi equiparada à entidade familiar, devendo receber o mesmo tratamento conferido ao casamento, em todos os seus aspectos.

Sendo assim, notável é o vício de inconstitucionalidade que contém o artigo 1.790 do Código Civil, em que deixa de lado elementos constitucionais da família como o afeto e a solidariedade, e privilegia laços biológicos distantes, de parentes colaterais de até $4^{\circ}$ grau, demonstrando uma imensurável incoerência.

Vale ressaltar que o Supremo Tribunal Federal, em 10 de maio de 2017, encerrou o julgamento sobre a inconstitucionalidade do artigo 1790 do CC. Conforme se observa preceituado no informativo $804^{15}$.

Por fim, ficou destacado que, com a finalidade de preservar a segurança jurídica, o entendimento sobre a inconstitucionalidade do art. 1.790 do Código Civil deve ser aplicado apenas aos inventários judiciais em que a sentença de partilha não tenha transitado em jul- gado e às partilhas extrajudiciais em que ainda não haja escritura pública. A tese final fir- mada, para os devidos fins de repercussão geral ${ }^{16}$, foi aquela conhecida desde o ano de $2016^{17}$.

E com essa decisão do STF resta a dúvida quanto o futuro dos companheiros ${ }^{18}$.

\footnotetext{
15 “O Supremo Tribunal Federal afirmou que a Constituição contempla diferentes formas de família, além da que resulta do casamento. Nesse rol incluem-se as famílias formadas mediante união estável. Portanto, não é legítimo desequiparar, para fins sucessórios, os cônjuges e os companheiros, isto é, a família formada por casamento e a constituída por união estável. Tal hierarquização entre entidades familiares mostra -se incom- patível com a Constituição. O art. 1.790 do Código Civil de 2002, ao revogar as leis 8.971/1994 e 9.278/1996 e discriminar a companheira (ou companheiro), dando-lhe direitos sucessórios inferiores aos conferidos à esposa (ou ao marido), entra em contraste com os princípios da igualdade, da dignidade da pes- soa humana, da proporcionalidade na modalidade de proibição à proteção deficiente e da vedação ao retro- cesso".

16 "no sistema constitucional vigente, é inconstitucional a diferenciação de regimes sucessórios entre cônju- ges e companheiros, devendo ser aplicado, em ambos os casos, o regime estabelecido no artigo 1.829 do Código Civil".

${ }^{17}$ Disponível em: http://www.stf.jus.br/arquivo/informativo/documento/informativo864.htm. Acesso em: 16 jul. 2020 .

18 "é importante observar que o tema possui enorme repercussão na sociedade, em virtude da multiplicidade de sucessões de companheiros ocorridas desde o advento do CC/2002. Assim, levando-se em consideração o fato de que as partilhas judiciais e extrajudiciais que versam sobre as referidas sucessões encontram-se em diferentes estágios de desenvolvimento (muitas já finalizadas sob as regras antigas), entendo ser recomendá- vel modular os efeitos da aplicação do entendimento ora afirmado. Assim, com o intuito de reduzir a insegu- rança jurídica, entendo que a solução ora alcançada deve ser aplicada apenas aos processos judiciais em que ainda não tenha havido trânsito em julgado da sentença de partilha, assim como às partilhas extrajudiciais
} 
Apesar de ter um posicionamento e decisão admiráveis, algumas questões ficaram pendentes no julgamento do STF. A primeira delas diz respeito à inclusão ou não do companheiro como herdeiro necessário no art. 1.845 do Código Civil, outra tormentosa questão relativa ao Direito das Sucessões e que tem numerosas consequências. O julgamento nada expressa a respeito da dúvida. Contudo, positivas mudanças aconteceram e novos efeitos se instauram em nosso ordenamento jurídico:

a) incidência das regras previstas entre os arts. 1.846 e 1.849 do CC/2002 para o companheiro, o que gera restrições na doação e no testamento, uma vez que o conviventedeve ter a sua legítima protegida, como herdeiro reservatário;

b) o companheiro passa a ser incluído no art. 1.974 do Código Civil, para os fins de rompimento de testamento, caso ali também se inclua o cônjuge;

c) o convivente tem o dever de colacionar os bens recebidos em antecipação (arts. 2.002 a 2.012 do CC), sob pena de sonegados (arts. 1.992 a 1.996), caso isso igualmente seja reconhecido ao cônjuge.

\section{CONCLUSÕES}

O presente artigo teve por objetivo discutir o tratamento em relação ao direito sucessório de cônjuges e companheiros.

Discorreu-se sobre a evolução da concepção de família, favorecendo-se a constituição de um núcleo familiar com base no afeto. Demonstrou-se mediante a jurisprudência, que o posicionamento dos julgadores, apesar de conflitante, direciona-se para o entendimento da inconstitucionalidade do art. 1790 do Código Civil, pois a forma como o legislador estabeleceu a sucessão do companheiro viola a equiparação constitucional entre casamento e união estável, como formas de constituição de família.

E foi na decisão do RE 878694/MG que o STF entendeu pela inconstitucionalidade do art. 1790, CC, por violação aos princípios da dignidade da pessoa humana, da igualdade e da proteção da família, estabelecendo a tese de que "no sistema constitucional vigente, é

em que ainda não tenha sido lavrada escritura pública" (STF, recurso extraordinário 878.694/MG, relator ministro Luís Roberto Barroso). 
inconstitucional a distinção de regimes sucessórios entre cônjuges e companheiros devendo ser aplicado, em ambos os casos, o regime estabelecido no art. 1829 do CC/2002”.

Portanto, deve-se aplicar à sucessão do companheiro o regime previsto para a sucessão do cônjuge, conforme os artigos 1829 e seguintes. Pois o artigo 1790 nada mais é que uma injusta abominação.

O legislador poderia ter avançado mais, porque o silêncio quanto a alguns pontos gera grande insegurança jurídica à sociedade como, por exemplo, a reserva da quota mínima atribuída ao cônjuge ser omissa quanto aos companheiros. Neste caso, não reside a injustiça em conceder menos direitos ao companheiro, mas aos filhos e parentes em razão da origem da família. Sem falar em algumas consequências jurídicas de não ser a união estável reconhecida como um novo estado civil.

Basta imaginar que durante a união estável, um dos companheiros tenha adquirido onerosamente um bem imóvel com registro apenas em seu nome e, uma vez que possui status jurídico de solteiro, poderá alienar o bem, fato que não elimina o direito do outro à meação.

Ao fim, o adquirente de um imóvel nessa situação, terceiro de boa-fé, que não tinha como saber que o imóvel não pertencia integralmente ao alienante, estaria sujeito a ver sua compra anulada.

A constituição da família por meio da união estável, como ocorre com o casamento, produz efeitos não somente entre os conviventes, ou entre eles e os seus filhos, mas à sociedade como um todo.

São palavras da ilustre desembargadora Maria Berenice Dias:

Se a sociedade muda e as relações entre as pessoas evoluem, as leis, para cumprirem seu papel de regrar a vida e estabelecer pautas de conduta, também têm que se plasmar às novas realidades. Da mesma forma, devem os operadores do Direito interpretá-las com uma visão que mais se identifique com ajustiça. (DIAS, 2007, p. 128)

E com estas palavras, esse artigo científico chega ao seu desfecho.

O artigo 1790 do Código Civil é, com toda certeza, inconstitucional. E não há que se falar o contrário, pois o próprio STF assim decidiu no ano de 2017 e há evidências suficientes para que assim seja considerado o aludido artigo. 


\section{REFERÊNCIAS}

BEVILÁQUA. Clóvis. Direito de Família. Rio de Janeiro: Ed. Rio, 1976.

BORTOLINI, Georgea. A Sucessão Na União Estável. Monografia submetida à Universidade do Vale do Itajaí, nov. 2007.

BRAVO, Maria Celina; SOUZA, Mário Jorge Uchoa. As entidades familiares na Constituição. Jus Navigandi, Teresina, ano 6, n. 54, fev. 2002. Disponível em: https://jus.com.br/artigos/2665/as-entidades-familiares-na-constituicao. Acesso em: 17 jul. 2020.

BUOSI, Caroline de Cássia Francisco. As Famílias Contemporâneas: Entidades Explícitas e Implícitas No Sistema Jurídico Brasileiro, 2012. Disponível em: http://www.publicadireito.com.br/artigos/?cod=38ca89564b225940. Acesso em: 17 jul. 2020.

CAHALI, Francisco José. Direito das Sucessões. São Paulo: RT, $3^{\text {a }}$ Edição, 2007, p. 189192.

DIAS, Maria Berenice. Alimentos a Vida. In: Revista Jurídica Consulex. Ano XII, n. 286, dez. 2008.

Manual de Direito Das Famílias. $10^{\mathrm{a}}$ Edição revista, atualizada e ampliada. São Paulo: Revista dos tribunais, 2015.

DINIZ, Maria Helena. Curso de Direito Civil Brasileiro. Direito de Família. São Paulo: Saraiva, 1990, p. 223- 324.Vol. 5.

HIRONAKA, Giselda Maria Fernandes; TARTUCE, Flávio. Comentários ao Código Civil. Coord. Antonio Junqueira de Azevedo. São Paulo: Saraiva, $2^{a}$ Edição, 2007, p. 228-229, Vol. 20.

LOBO, Paulo Luiz Netto. Entidades Familiares Constitucionalizadas: Para Além Do Numerus Clausus. Revista IBDFAM, 12, jan/fev/mar. 2002.

MIRANDA, Pontes. Tratado de Direito Privado, 92ª Ed., Rio de Janeiro: Borsoi, 1960

SIMÃO, José Fernando. Direito Civil. Direito das Sucessões. $3^{\text {a }}$ Edição. São Paulo: GEN/Método, 2010, Vol 6.

TARTUCE, Flávio. Direito Civil: Direito das Sucessões, 6. 7 ed. São Paulo: Método, 2014. 
VELOSO, Zeno. Direito Hereditário do Cônjuge e do Companheiro. São Paulo: Saraiva, 2010.

VENOSA, Sílvio de Salvo. Direito Civil: Direito das Sucessões. $11^{\mathrm{a}}$ edição. São Paulo: Editora Atlas, 2011. Vol. 7. 